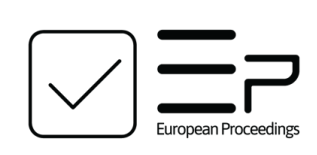

European Proceedings of

International Conference on Education \&

Educational Psychology

EPICEEPSY

www.europeanproceedings.com

e-ISSN: 2672-8141

DOI: $10.15405 /$ epiceepsy.21101.20

ICEEPSY 2021

$12^{\text {th }}$ International Conference on Education \& Educational Psychology

\title{
VICTORIES OVER IMPENDING DEATH AMONG THE TERMINALLY-ILL
}

\author{
Monika Ulrichová (a)* \\ *Corresponding Author \\ (a) Department of Practical Theology, Protestant Theological Faculty, Charles University, Černá 646/9, 11555 Praha \\ 1, Czech Republic, ulrichova.monik@seznam.cz
}

\begin{abstract}
In most cases, the diagnosis of terminal disease is accompanied by uncertainty and anxiety. People are most concerned that they will die in pain or alone. A therapist working with the terminally ill should take the issue of concerns regarding death seriously and be able to deal with it to the utmost possible extent. Diagnosis of a serious illness is always a shock for patients. They are usually unable to process their feelings in order to overcome the bad news. Then comes the reality in the form of surgery, treatment, limitation of activities, profession and the needs of the terminally ill to cope with all their emotions. This exploratory qualitative study attempts to uncover the emotions of the terminally ill through a series of interviews. The findings reveal that after the initial struggle of accepting the diagnosis, they move on to a series of positive outcomes for themselves such as a sense of liberation and appreciation of the simple things that life has to offer. Relationships too are simplified and enjoyed to the fullest. These findings have significant implications for the planning of appropriate care for the terminally ill.
\end{abstract}

2672-8141 (C) 2021 Published by European Publisher.

Keywords: Terminally-ill, client, dying, paliative care, values

(C) The Author(s). This work is licensed under a Creative Commons Attribution-NonCommercial-NoDerivatives 4.0 International License (http://creativecommons.org/licenses/by-nc-nd/4.0/). 


\section{Introduction}

People's physical, mental, emotional and spiritual needs, are by default, crucial to them as sources of contentment. Hence, it is no surprise that if any of these are affected by unfortunate circumstances, people will react negatively. This is especially so in times of serious illness, or in the face of death. At such times, one always returns to what is left here on earth, especially in the mental and emotional sense. When death is inevitable, it matters little matters how much money they have made, what assets they have bought and their status. Experience with dying people shows that people care mainly about relationships (Ulrichová, 2014).

Birth and dying are obscured by mystery. The significant shift in the field of giving birth, from the application of medical procedures to the preservation of the naturalness of this process should be similarly mirrored in the need to study the processes involved in dying and death.

During pregnancy, plans are made where and, even how the baby should be born. Arrangements are made regarding the facility in which the birth will occur, the medical personnel involved and so on. Close friends and family are involved in this significant event. So much time and effort are invested in the birth of a new life. However, this is not the case with death, which is no less of a significant event, signifying the end of a life. At this point, conversations should be initiated with the dying person, on their emotions and needs, and how these may be satisfied to allow the person an emotional and mental "peace" before they pass on.

With loved ones who are dying, the focus should be on how they want to spend the last days of life, what activities are important to them and especially, may to prevent the dying from dying well. Therefore, it is very important to focus on ensuring that people are reconciled in terms of their relationships. Miroslav Sígl (2017) also often talks about death stating that in death we seem to return to life.

Fear and anxiety play a significant role in the dying process. In addition to thanatology, the fear of death is dealt with in many other disciplines - philosophy, sociology, nursing, anthropology, law, pedagogy, theology, history and politics. However, psychology and medicine are the most significant.

The whole concept of focusing on the needs of the dying was new to the medical and psychological fields until Elisabeth Kübler-Ross, a Swiss-born American psychiatrist, brought it to the forefront with her ground-breaking book entitled On Death and Dying published in 1969 where she mooted the concept of providing psychological counseling to the dying. She proposed the now famous Stages of Grief framework which she used to elaborate the five stages - denial, anger, bargaining, depression, and acceptance - which she posited the dying go through. Additionally, she pushed for the acceptance of death as part of life, offering interventions that psychiatrists and medical personnel could use to help patients and their families through the stages of grief.

The following site https://cfmedicine.nlm.nih.gov/physicians/biography_189.html gives an indepth account of her life and experiences that led to her accomplishments in this area.

Borgstrom and Ellis (2017) as guest editors of the special issue entitled Promoting the interdisciplinary study of death and dying delineate research undertaken in this area as follows:

If we look at the genealogy of death studies (in English-speaking nations at least), there is a history of key periods of academic reflection and activity. For example, in the late 1960s and early 1970s (in the 
United States in particular), we saw a plethora of research in the field which produced seminal works that are still regularly cited in research, teaching and professional education today (e.g. Glaser \& Strauss, 1965; Kubler-Ross, 1969). In the 1990s, many important theoretical (e.g. Mellor \& Shilling, 1993; Walter, 1994) and empirical (e.g. Hockey, 1990; Howarth, 1996; Young \& Cullen, 1996) texts where published along with a number of edited collections (e.g. Clark, 1993; Klass, Silverman, \& Nickman, 1996). Now, in the 2010s, we have several further diverse and novel contributions to the field, (e.g. Cann, 2014; Christensen \& Willerslev, 2013; Foster \& Woodthorpe, 2016; Kellehear, 2014).

It is thanks to Kubler-Ross' work that the world, in particular the Czech Republic, has become more sensitized to the processes associated with dying and has stimulated more publications in this area. Yet, it can be said that the issue of dying and death is still treated as taboo in many societies.

\section{Problem Statement}

Dying and death are still perceived as something elusive, extraordinary and of course everything is complicated by a certain "unrepeatability" (Ulrichová, 2014). In her previous research conducted with cancer patients, Ulrichová (2014) focused on identifying positives that emerged for them during that difficult situation, despite all the suffering that cancer had inflicted upon them. Despite the acknowledged difficulties in conducting such research from a psychological point of view, it was necessary to highlight the fact that some 'good' does exist even in such a taboo subject as death.

Several scholars working in this area have touch on the issue of dying well (Byock, 1997; Haškovcová, 2000). Everyone would like to die well. Dying well expresses the very meaning of living and the act itself, which often resonates with a sense of courage. Haškovcová (2000) contends that dying well is a prevention against those people who are considering euthanasia. If people are well cared for, they will not think that they are a "burden" to others. This alleviates the desire to leave their life prematurely.

Research conducted with the dying reveals that the sick are not afraid of the death itself, but rather of the dying process, lack of self-sufficiency and, above all, loneliness in dying (Ulrichová, 2014). The initial shock of getting the bad news is often followed by inner turmoil compounded by the reality of surgery, therapy, and the end of their social and professional life. There are fears for the future, anger and remorse, sometimes directed by the patients themselves towards others. It is during this period that it becomes crucial to listen to the patients' feelings. Heyse-Moore (2008) highlights the importance of talking to dying people and the support of family members. For psychotherapists, it is a considerable challenge because the experiences are often coloured with anxiety.

\section{Research Questions}

The following questions aimed to identify the following.

3.1 What are the experiences faced by the terminally ill?

3.2 Has the process uncovered anything valuable or positive? 


\section{Purpose of the Study}

In human life, there comes a point of no return. This point is dying, which needs to be acknowledged and focused on in terms of providing the best care during this process. The important thing is that the dying have what they need to ease the process. Kosová (2014) provided the following revelations for care givers, family and psychotherapists to understand the innermost feelings of the dying.

a) Do not allow me to be humiliated in the last moments. Let me die in an intimate environment. That is harder for you, however, it is enriching for you to be a dying guide.

b) Stay with me even when I am angry, afraid, sad and in despair. Do not think I am dead when you sit on my bed. Life takes longer than doctors say. The transition is longer than we previously knew. I can hear everything you say even when I am silent, and my eyes look dead. Therefore, do not say anything - say only the right thing.

c) The right thing you can tell me, if I cannot ask you for it anymore, would be what would not make it difficult, but easy for me to leave. Because I have to. Show me the courage to deal with it, not the unsustainable pain. Compassion is not in place. I no longer suffer.

d) The right thing you can say now, even if I cannot ask you for it anymore, is the word I lived with. Try to find it and whisper it in my ear, I can hear you.

e) I hear, though I have to keep quiet and I want to keep quiet. Hold my hand. Wipe my sweat from my forehead. Stay with me, we are connected to each other.

f) Now you can learn from me more than I can learn from you. Now I am leaving, say thanks.

g) Tomorrow, take care that the tone of this hour is not lost between us. When death moves on and on, and the last condolences are answered, and you fall into sorrow, defend yourself with all your might. Take with you what we have shared together as a precious will. Make your life more beautiful, mature and deep.

\section{Research Methods}

\subsection{Research design and instrument}

This research took place in an oncology clinic in Hradec Králové in the Czech Republic with 25 terminally ill cancer patients. Understandably the research design is qualitative in nature, where semistructured interviews were utilised to allow for patients' testimony to be shared as they wished. Their responses directed the flow and shape of the subsequent questions. Technical preparation is required before a semi-structured interview during which a scheme is constructed, which is further specified for the questions areas (Miovský, 2006, p. 159). It is not necessary to have a set order of questions, because the sequence of questions changes according to the needs and possibilities of the current interview. Miovský (2006, p. 160) introduces the term "core of interviews" to create a semi-structured interview, which means the minimum of topics and questions that the interviewer should discuss with the respondent. Other questions and topics that have an expanding character are then packed into this core. Questions for this type of research were specific to the patients being interviewed; hence, they were not adapted from any other study but were formulated with the research questions and sensitivity to the patients' condition in mind. 
During the preparation, questions were formulated regarding the quality of life of a person with a cancer diagnosis. All the patients were first acquainted with the research needs and need for the interview. They were informed that the interview was completely voluntary and that all data were anonymized. The interviews took place in the visiting room or the patients' room.

Since this is an extremely sensitive area, the ethical aspects of this research are important to mention. According to Miovský (2006), "Ethical rules and standards must be considered at least at three basic levels - the researcher's influence on the research field and its retrospective influence in the field, the protection of research participants, the protection of the researcher (s)" (p. 277). Hendl (2005) describes the ethical principles of conduct in research, such as informed consent to participate in research, providing active or passive consent to participate in research, maintaining the anonymity of participants, and secrecy of research information to research participants.

During this research, the participant was always informed about the facts concerning ethical principles. For this study, the participants were acquainted with the information about the course of the interview, the anonymity of the research and the recording on the Dictaphone in the phone call that preceded the personal meeting. At the beginning of the recording, each participant additionally confirmed the agreement with the given recording.

\subsection{Analysis of obtained data}

The interviews were recorded on a dictaphone and each audio recording was then converted into text via transcription (Miovský, 2006, p. 205). This was followed by encoding the obtained data. Coding lies at the heart of qualitative data processing and sorting. It is a process in which we convert the original data into data units, by which we identify or assign names (Miovský, 2006, p. 201). According to Strauss and Corbin (1999, p. 39), coding is an operation in which data is analysed, conceptualized, and reassembled in new ways. The text colouring technique was used for better orientation in the transcribed interviews. The parts of the text that were similar to each other from the statements of individual respondents were coloured. The parts marked in this way represented the mentioned codes or general categories. The method of creating clumps was used as a method of analysis of the obtained qualitative data. This method is used to group and conceptualize certain statements into groups, for example, according to the distinction of certain phenomena, cases, etc. (Miovský, 2006, p. 221). These groups arise from overlaps and similarities between identified units (Miovský, 2006). Subsequent categorization of selected basic units creates more general units.

\section{Findings and Discussion}

The data analysis of the interviews with the patients revealed the following as major concerns:
a) if they are young, they worry about their children
b) pain during oncological disease
c) loneliness
d) what occurs after death 
e) about relatives especially if they are sick

The following emerged as positives for the particpants:

a) They stopped working.

b) They have more time for themselves.

c) They plan their time by themselves.

d) They appreciate the effort and care of doctors and nurses.

e) They enjoy their days more; it's a miracle for them to be able to go into the garden

f) They appreciate people whom they took for granted

Below is a sample interview with a participant terminally-ill with pancreatic cancer.

\section{Interview 14}

MU: So Mrs. D., thank you for the interview. I was going to ask.

P: Do you mind if I lie like this?

MU: I don't mind at all. What is your experience of the illness that you have?

P: Well, I came to terms with it about a year ago, so we'll see, like, what's in store for me.

MU: You've come to terms with it, have you?

P: It was kind of worse at first, well, I thought there would be some chance, well. Um, so it's not worth it anymore. So I'm kind of resigned to it now.

MU: And you're at peace with what exactly?

P: Well, that it's all going to get worse. Then I don't know, well, then if they'll put me somewhere or...

MU: So what kind of illness do you have?

P: Pancreas.

MU: Pancreas.

MU: So the pancreas. How did it start? Describe it to me a little bit.

P: It started when my...my whites turned yellow.

MU: And that was when? When did your whites turn yellow?

P: My whites turned yellow in June 2016.

MU: So 2016 it started.

P: Well, and then I went to the doctor the next day, only it was in June, it was hot. I was like, I felt so weird, I was like, it must be from the heat at work. Well, it was warm outside, well, I went to the doctor, to the doctor's office. He took my urine. I think it was urine. And it showed something, I don't know. So he, like, sent me for an ultrasound, a C.T., and I was fine. And then I was admitted here for treatment.

MU: And did they tell you what was wrong with your pancreas, that you had inflammation or cancer? 
P: No, they told me right away that there was a tumour there.

MU: That it was a pancreatic tumour, yeah.

P: After the, after the, after the, after the ultrasound actually.

MU: And how old are you, Mrs. D.?

P: Sixty-one.

P: It was the same for a while, then it got worse, then they gave me something else. Well, now the last time last summer they gave me some radiation, that it was like more of the body, that it was enough to like finish, actually, the other one, then they also said that it was still pushing somewhere in my stomach. Well, they're worried that it's gonna burst somewhere.

MU: Yeah, that it's pushing into your stomach, hmm. Well, what did it mean to you when you found out you had a pancreatic tumour? How did you feel about it, how did you experience it? P: At first I thought I was just going to be okay, well, fight it out and get through it. Um, sort of, although the doctor told me straight away to get my affairs in order. I thought maybe I'll just be here for a month, to see what's going on around me like. Anyway, I just had to kind of deal with it, so nothing, well.

MU: And what helped you cope with that?

P: Erm, I don't know, when I was well, after that first chemo I was like quite bad, so I was like, I didn't take it well, I was like... Well, and then after some more chemo I was like better, well, I don't know, somehow. They were bad at home.

MU: At home means who, the husband?

P: Husband, kids, I have friends, well.

MU: How old are your kids?

P: Daughter's 40, boy's 33.

MU: How did they accept that you had such a serious illness?

P: Well, it's probably hard, but they didn't cry, I mean, well.

MU: Um, and what did they say, how did they cope with it? Did you talk about it differently?

P: Well, my husband didn't really want to talk about it. Well, and with my daughter, when we talked about it, she said that they would help me, that they would take care of me.

MU: Hmm, and that's actually been going on for four years, right? Hm, so that family helped you cope.

P: Yeah, I mean, I'm still crying a little bit, well, I'd rather not.

MU: And why are you crying now? What's in those tears?

P: Well, in those tears then is the, kind of the joy of, like, being able to live to like.

MU: I'm glad there's joy in that.

MU: What are those days like when you're home? How do you spend it at home?

P: Well, when I was well then, too. I'm kind of cheerful then too, I make fun of myself. 
MU: So you like humour, too.

P: I do, well, and then in the afternoon, when my husband comes home from work, my husband is with me, maybe the kids come.

MU: What would you say you miss now? What do you miss?

P: Now? Now I miss that I have to be here and that I can't be at home. You know what, I just lie here, right, I go to the bathroom, open the window, have a snack. At home I can look out the window, people come in during the day.

MU: Now I'm going to ask you a more difficult question, despite the illness, would you find anything positive about it? About the whole situation that has arisen?

P: Well, I guess so. I guess it's like, I 'm on disability retirement and actually the program and everything I plan the way I want to. That I don't have to submit and I don't have to go to work and I don't have to go shopping and I don't have to wash the windows. I just don't do that at all anymore. I don't care about windows or shopping.

MU: So there's a kind of freedom, freedom. There's a freedom in that.

P: And when I go somewhere, I just write a note on the table that I'm going somewhere, and I take my phone with me, right. And I do what I want too, right. So I don't say to myself, I still have to iron my husband's shirts, clean the laundry. All that stuff. It's a little more relaxing.

MU: What are you worried about right now, is there anything you need to be worried about?

P: I guess I don't. I've got the bluebonnets blooming now, the daffodils. And when they are disappearing, right, I'm like, who knows if I'll still be around next year.....

\section{Conclusion}

Based on the data obtained it can be inferred that some positives have emerged despite their condition which has made them ponder and reflect more about life. Some realised the satisfaction of finally having more time to themselves and being able to plan their own lives on their own terms. They began to appreciate things and people they had previously taken for granted.

The patients themselves report stunning shifts and internal changes that cannot be described as anything other than personal growth (Yalom, 2006).

- Reconfiguration of life values - recognising the non-essential as trivial

- Feeling of liberation - the ability not to do what I don't want to do

- An enhanced experience of living in the present moment rather than putting life off until retirement or some other time in the future

- Joyful appreciation of the basic things in life - changes of season, wind, falling leaves, past Christmases...

- Deeper communication with loved ones than before the crisis

- Less fear of interpersonal relationships, greater readiness to take risk than before the crisis 
These findings may be valuable for care givers and psychotherapists in planning the appropriate interventions to deal with terminally ill. It is valuable for medical staff and psychotherapists to know that despite the horror of suffering from a terminal illness, there can be "benefits" from the experience which can be leveraged to ease the process of transition from life to death for the terminally ill. Furthermore, these results may even be interesting for the patients themselves, their family members and other concerned people like religious people who may have to deal with such situations.

\section{References}

Byock, I. (1997). Dobré umiráni: možnosti pokojného konce života [Good dying: the possibility of a peaceful end to life]. Vyšehrad.

Borgstrom, E., \& Ellis, J. (2017). Introduction: Researching Death, Dying and Bereavement, Mortality, 22(2), 93-104. https://doi.org/10.1080/13576275.2017.1291600

Cann, C. (2014). Virtual Afterlives: Grieving the Dead in the Twenty-First Century. The University Press of Kentucky.

Christensen, D. R., \& Willerslev, R. (2013). Taming Time, Timing Death: Social Technologies and Ritual. Ashgate.

Foster, L., \& Woodthorpe, K. (Eds.). (2016). Death and Social Policy in Challenging Times. Palgrave Macmillan.

Glaser, B. G., \& Strauss, A. L. (1965). Awareness of dying. Aldine Transaction.

Haškovcová, H. (2000). Thanatologir: nauka o umiráni [Thanatologir: the science of dying]. Praha: Galén.

Hendl, J. (2005). Kvalitativní výzkum: základní metody a aplikace [Qualitative research: basic methods and applications]. Portál s. r. o.

Heyse-Moore, L. (2008). Speaking of Dying: Practical Guide to Using Counselling Skills in Palliative Care. Jessica Kingsley Publishers.

Kellehear, A. (2017). Current social trends and challenges for the dying person. In N. Jakoby, \& M. Thönnes (Eds.), Zur Soziologie des Sterbens: Aktuelle theoretische und empirischeBeiträge (pp. 1127). Wiesbaden, Germany: Springer.

Klass, D., Silverman, P. R., \& Nickman, S. L. (Eds.). (1996). Continuing bonds: New understandings of grief. Taylor \& Francis.

Kosová, M. (2014). Logoterapie [Logotherapy]. Grada Publishing

Kubler-Ross, E. (1969). On Death and Dying. Macmillan.

Mellor, P. A., \& Shilling, C. (1993). Modernity, self-identity and the sequestration of death. Sociology, 27(3), 411-431.

Miovský, M. (2016). Kvalitativni pristup a metody v psychologickém výzkumu [Qualitative approach and methods in psychological research]. Grada Publishing.

Sígl, M. (2017). Co víme o smrti...? [What do we know about death...?]. Olympia.

Strauss, A., \& Corbinová, J. (1999). Základy kvalitativniho výzkumu: postupy a techniky zakotvené teorie [Fundamentals of qualitative research: procedures and techniques of grounded theory]. Albert.

Ulrichová, M. (2014). Hledáni smyslu ve smrti a umírání [Searching for meaning in death and dying]. Moravapress.

Walter, T. (1994). The Revival of Death. Routledge.

Yalom, I. D. (2006). Existenciální psychoterapie [Existential psychotherapy]. Basic Books.

Young, M., \& Cullen, L. (1996). A Good Death: Conversations with East Londoners. Routledge. 